\title{
Influence of oxygen in the development of retinopathy of prematurity
}

\author{
Influência do oxigênio no desenvolvimento de retinopatia da prematuridade \\ Influencia del oxígeno en el desarrollo de retinopatía del prematuro
}

\section{Joziana Pastro' \\ ORCID:0000-0003-1906-9481}

Beatriz Rosana Gonçalves de Oliveira Toso'

ORCID: /0000-0001-7366-077X

'Universidade Estadual do Oeste do Paraná - UNIOESTE. Cascavel, Paraná, Brasil.

How to cite this article:

Pastro J, Toso BRGO. Influence of oxygen in the development of retinopathy of prematurity. Rev Bras Enferm. 2019;72(3):592-9. doi: http://dx.doi.org/10.1590/0034-7167-2018-0361

\section{Corresponding Author:}

Beatriz Rosana Gonçalves de Oliveira Toso E-mail: beatriz.oliveira@unioeste.br Submission: 06-04-2018 Approval: 03-08-2019

\begin{abstract}
Objective: to describe the influence of oxygen in retinopathy of prematurity (ROP) in premature newborns (PTNB) hospitalized in neonatal units of intensive care and undergoing ophthalmological follow-up procedures after hospital discharge. Method: retrospective cohort study, from January 2014 to June 2016, whose data collection totaled 181 charts. Descriptive and inferential statistical analysis. Results: when using oxygen $\left(\mathrm{O}_{2}\right)$ in 148 PTNB $(81.7 \%)$, both mask $(n=141 ; 77.9 \%$; $p$-value $<0.001)$ and the tracheal tube predominated $(n=100 ; 55.25 ; p$-value $<0.001)$ for 15 days in average. The time of use and $\mathrm{O}_{2}$ concentration of the tracheal tube ( $p$-value $<0.001$ ), the time of mask use ( $p$-value $<0.001$ ) and the time and concentration of $\mathrm{O}_{2}$ of the continuous positive airway pressure (CPAP) ( $p$-value $<0.001$ ) were significant to cause ROP in 50 PTNB (11.31\%). Conclusion: the oxygen therapy has influenced the development and severity of ROP, indicating the need to adopt protocols for its use.

Descriptors: Retinopathy of Prematurity; Oxygen; Preventive Health services; Premature Newborn; Nursing.
\end{abstract}

\section{RESUMO}

Objetivo: descrever a influência do oxigênio na retinopatia da prematuridade (ROP) em recém-nascidos prematuros (RNPT) hospitalizados em unidade de terapia intensiva neonatal e em seguimento pós-alta hospitalar por serviço de oftalmologia do Paraná. Método: estudo de coorte retrospectivo, em recorte temporal de janeiro de 2014 a junho de 2016, com coleta de dados em 181 prontuários. Análise estatística descritiva e inferencial. Resultados: utilizaram oxigênio $\left(\mathrm{O}_{2}\right) 148$ RNPT $(81,7 \%)$, predominando máscara ( $n=141 ; 77,9 \%$; $p$-valor $<0,001)$ e tubo orotraqueal (TOT) $(n=100 ; 55,25 ; p$-valor $<0,001$ ), em média por 15 dias. O tempo de uso e a concentração de $\mathrm{O}_{2}$ de TOT ( $p$-valor $<0,001$ ), tempo de uso de máscara ( $p$-valor $<0,001$ ) e tempo e concentração de $O_{2}$ do continuous positive airway pressure (CPAP) ( $p$-valor $<0,001)$ foram significativos para desencadear a ROP em 50 (11,31\%) RNPT. Conclusão: a terapêutica com oxigênio influenciou no desenvolvimento e gravidade da ROP, indicando a necessidade de adoção de protocolos para seu uso.

Descritores: Retinopatia da Prematuridade; Oxigênio; Serviços Preventivos de Saúde; Recém-Nascido Prematuro; Enfermagem.

\section{RESUMEN}

Objetivo: describir la influencia del oxígeno en la retinopatía del prematuro (ROP) en recién nacidos prematuros (RNPT) hospitalizados en unidad de cuidados intensivos neonatal y en seguimiento tras alta hospitalaria por servicio de oftalmología del estado del Paraná, en Brasil. Método: estudio de cohorte retrospectivo, en recorte temporal de enero del 2014 a junio del 2016, con recolección de datos en 181 fichas clínicas. Análisis estadístico descriptivo e inferencial. Resultados: utilizaron oxígeno $\left(\mathrm{O}_{2}\right) 148$ RNPT ( $81,7 \%)$, predominando máscara $(n=141 ; 77,9 \%$; $p$-valor $<0,001)$ e intubación orotraqueal (TOT) $(n=100 ; 55,25 ; p$-valor $<0,001)$, alrededor de 15 días. El tiempo de uso y la concentración de $\mathrm{O}_{2}$ de TOT ( $\mathrm{p}$-valor $<0,001$ ), tiempo de uso de máscara ( $\mathrm{p}$-valor $<0,001$ ) y tiempo y concentración de $\mathrm{O}_{2}$ del continuous positive airway pressure (CPAP) ( $p$-valor $<0,001$ ) fueron significativos para desencadenar la ROP en $50(11,31 \%)$ RNPT. Conclusión: la terapéutica con oxígeno influyó en el desarrollo y gravedad de la ROP, indicando la necesidad de adoptar protocolos para su uso.

Descriptores: Retinopatía del Prematuro; Oxígeno; Servicios Preventivos de Salud; Recién Nacido Prematuro; Enfermería. 


\section{INTRODUCTION}

Due to advances in technology and in the treatment of premature children, there is a change in the viability limit towards increasingly lower gestational ages at birth. The lower limit of viability has been set between 22 and 28 gestational weeks and among other factors, depends on the technical capacity of perinatal care of the place where the birth occurs, as well as the ethical aspects that involve the question ${ }^{(1)}$. According to the World Health Organization (WHO), the viability limit is around 20 gestational weeks on, considering the neonatal mortality rate before that is $100 \%^{(2)}$.

A total of 13 million premature births occur in the world every year. From these, 11 million cases (85\%) are concentrated in Africa and Asia. Brazil is among the 10 nations with the highest number of premature births, and $9.2 \%$ of all births that occurred in the country by 2010 were premature. A value lower than the prevalence of $11.3 \%$ previously recorded by a national hospital-based study in 2013, suggesting an increase in premature birth rate in the country ${ }^{(3)}$.

Hence, the growing scientific and technological advances contributed to the increase in the survival rates of premature newborns (PTNB), with positive changes in infant mortality profile. The hospitalization of a PTNB in a neonatal intensive care unit (NICU) stems from prematurity and/or low birth weight associated with respiratory complications, among other complications ${ }^{(4)}$.

Within the care needs of the NICU, one of the most frequently associated with prematurity and pulmonary immaturity is oxygen therapy. Its use in PTNB, however, may have toxic effects, especially in the retina and in the lungs, so there is need to strike a balance between indications and contraindications arising from its prolonged use ${ }^{(5)}$.

One of the consequences of the use of oxygen therapy in PTNB is retinopathy of prematurity (ROP) (6), which is an abnormal growth of fibroblast tissue and blood vessels later juxtaposed to the crystalline that can cause bilateral blindness in premature children without intervention. Terry has described it 50 years ago and according to him, during its natural progress, it generates a high social and financial cost for society, and can lead to permanent vision impairment, also affecting the child's cognitive and psychomotor development ${ }^{(7)}$.

In 2005, the ROP International Classification established parameters to evaluate the disease, including location, extent, severity and the presence of the plus disease. In 1954, the International Classification of Retinopathy of Prematurity divided the retina into three zones centered in the optical disk: zone I, corresponding to the posterior pole comprises the circle whose radius is twice as big as the distance from the optical disk to the fovea. Zone II extends from the edge of zone I to the nasal ora serrata and temporal equator. While zone III represents the remaining temporal pole, being later vascularized and, therefore being the most affected in $\mathrm{ROP}^{(8)}$.

The classification of ROP severity consists of five steps: ROP 1 - identification of the flat white line that separates the vascular retina from the avascular one; ROP 2 - widening of the demarcation line and the presence of high crest; ROP 3 - presence of fibrovascular proliferation, from the crest, leaving the retina; ROP 4 - presence of subtotal retinal detachment; and ROP 5 - total retinal detachment (open or closed funnel) $)^{(6)}$.
As for the prevalence of ROP, a study that approached the Brazilian health care service noted its presence in $37.81 \%$ of newborns, stage 1 showing up as the most prevalent one. We did not verify differences between the sexes $(p=0.993)$. However, the presence of ROP was bigger in the group with birth weight $<1,000 \mathrm{~g}(83.33 \%)^{(9)}$. In another investigation carried out in the country, ROP incidence was of $44.5 \%{ }^{(10)}$. In a literature review carried out in Iran, the authors found 42 studies that evaluated 18,000 premature newborns and indicated a prevalence of ROP of $23.5 \%{ }^{(11)}$. In the United States, the incidence of ROP has increased from $14.7 \%$, by 2000 , to $19.88 \%$, by 2012 , affecting around $30.22 \%$ of PTNB ${ }^{(12)}$.

From the mentioned above, it is possible to assume that ROP in premature newborns is not like the other types of ROP. There is a lack of studies that evaluate its prevalence and risk factors associated with each reality of care to prevent this serious problem in child health. In addition, we also noted a knowledge gap on ROP data in the study.

The guidelines for ROP prevention ${ }^{(13)}$ guide us to develop screening programs to identify PTNB at risk that need treatment, highlighting that ROP primary prevention should consider a strict oxygen administration and monitoring policy to avoid recurrent episodes of hypoxia and hyperoxia, actions directly associated with the nursing practice in NICU.

Both for the care routines of PTNB and the administration of oxygen, blood transfusions, and even ROP screening, there is a need for operational protocols to standardize these practices in the NICU, activities under the responsibility of the nursing teams. This way, to manage the screening, prevention and care protocols, it is necessary to assess the reality of NICU regarding this matter.

\section{OBJECTIVE}

To describe the influence of oxygen in the development of ROP among PTNB hospitalized in a NICU and undergoing ophthalmological follow-up after hospital discharge.

\section{METHOD}

\section{Ethical aspects}

This study followed all ethical precepts and was approved by the Research Ethics Committee of the State University of Western Paraná (Unioeste).

\section{Design, local and period of study}

Retrospective cohort study from medical charts of PTNB of two services from January 2014 to June 2016. In this study, past studies identified the exposed (PTNB who have developed ROP) and not exposed (PTBN who have not developed ROP) PTBN in the previously mentioned timeframe to assess participant's morbidity experience with ROP.

The first service is a public NICU hospital, with ten beds, in a municipality of Western Paraná, whose main hospitalizations are due to premature newborns. It is also a high risk reference institution of the Health Department of Paraná. The second one is an ophthalmologic outpatient service, in the same municipality, 
which carries out the referral of screened PTNB patients to ROP follow-up, as a reference service to the cited NICU.

At first, from all the cases that went through the ophthalmologic follow-up clinic, we identified those PTNB who underwent the follow-up service after referral by this NICU. Then, we located the patients' medical charts in the hospital institution and the follow-up service to use it as our research data.

\section{The population under study, inclusion/exclusion criteria}

In adopted temporal cut, there were 442 hospitalizations of PTNB in the NICU. From these, 181 (40.95\%) were evaluated through the ROP screening service and referred to follow-up in the ophthalmological outpatient clinic, being considered as the intentional study sample. The inclusion criteria of this study implied the need for participants to be premature newborns, who have been hospitalized in NICU during the established timeframe, who have also been evaluated for ROP screening during hospitalization or after discharge by the follow-up service. As an exclusion criterion, we defined newborn patients who ended up passing away.

\section{Study protocol}

After identifying all the medical charts, the researcher carried out direct data collection in the file and statistics departments of both institutions with the help of scientific initiation student under supervision. We filled the data collection instrument manually from the printed charts that addressed information on patients' socio-demographic context, the gestational period, birth, PTNB's general health history, oxygen therapy, the type of contribution, days of permanence and offered quantities, received treatments, as well as the detailed information on the evaluations, the ophthalmologic conducts and diagnosis associated with ROP.
Ophthalmological evaluations were performed every week by two ophthalmologists specialized in retina who monitored and/or treated patients according to their needs. The mentioned service has as ROP screening criteria PTNB with four weeks of life, who were born with less than 37 weeks of gestational age and who weighted less than $2,000 \mathrm{~g}$. The PTNB who were not evaluated in the NICU for not meeting the screening criteria during hospitalization were guided to evaluation of the in the referral service, reason why the charts of this service were also part of the study.

\section{Analysis of the results and statistics}

Data analysis was based on the the following steps: typing the data in an Excel for Windows 2010 database; using descriptive statistics and inferential statistics to analyze all data, which are contained in the tables.

As for the clustering, the coefficient of cophenetic correlation obtained was equal to 0.9637 and 0.9338 , respectively, for the first and second groups. These values were above 0.7 , indicating that the clustering method was appropriate. The $p$-value from the Fisher's exact hypothesis test represented significant results at a probability of $5 \%(p \text {-value }<0.05)^{(14)}$.

For the clustering by complete-link and simple-link methods,we considered the dissimilarity measure between the different analyzed elements, expressed by the measure that represents the product-moment correlation coefficient, quantifying the association between the items.

\section{RESULTS}

Regarding the use of oxygen by the PTNB hospitalized in the NICU, Table 1 describes the type of equipment and/or device used, time of use, as well as the concentration of oxygen used.

Table 1 - Use oxygen according to the type of offer, time of use and oxygen concentration (N=181). Cascavel, Paraná, Brazil, 2017

\begin{tabular}{|c|c|c|c|c|c|c|c|c|c|c|}
\hline Oxygentherapy & Yes & $\%$ & No & $\%$ & Min. & Mdn. & Max. & Avg. & $\begin{array}{l}\text { Standard } \\
\text { Deviation }\end{array}$ & $\begin{array}{c}\text { Variability } \\
\text { coefficient (\%) }\end{array}$ \\
\hline Use of Oxygen & 148 & 81.77 & 33 & 18.23 & & & & & & \\
\hline Use of Tube & 100 & 55.25 & 81 & 44.75 & & & & & & \\
\hline Tube Time & & & & & 1.00 & 7.00 & 74.00 & 15.14 & 16.68 & 110.15 \\
\hline [\%] Tube & & & & & 14.00 & 39.71 & 70.00 & 39.34 & 8.44 & 21.47 \\
\hline Use of mask & 141 & 77.90 & 40 & 22.10 & & & & & & \\
\hline Time with the mask & & & & & 1.00 & 5.00 & 52.00 & 9.10 & 8.65 & 95.07 \\
\hline [\%] Mask & & & & & 17.50 & 35.00 & 58.00 & 35.25 & 5.20 & 14.75 \\
\hline Use of positive pressure catheter & 58 & 32.04 & 123 & 67.96 & & & & & & \\
\hline Catheter time of positive pressure & & & & & 1.00 & 4.00 & 26.00 & 6.48 & 6.83 & 105.39 \\
\hline [\%] positive pressure in the catheter & & & & & 17.00 & 67.53 & 55.40 & 38.08 & 7.06 & 18.55 \\
\hline Use of Halo & 10 & 5.52 & 171 & 94.48 & & & & & & \\
\hline Halo time & & & & & 1.00 & 1.50 & 3.00 & 1.60 & 0.70 & 43.70 \\
\hline [\%] Halo & & & & & 30.00 & 40.00 & 73.30 & 45.33 & 12.58 & 27.76 \\
\hline Use of SB & 181 & 100.0 & 0 & 0.00 & & & & & & \\
\hline Time RE & & & & & 1.00 & 16.00 & 53.00 & 18.65 & 9.77 & 52.42 \\
\hline [\%] RE & & & & & 21.00 & 21.00 & 21.00 & 21.00 & 0.00 & 0.00 \\
\hline
\end{tabular}

Source: Research database. 2017. Caption: Min. -Minimum; Mdn.-Median; AVG. -Average; Orotracheal Tube - Tube; Catheter-continuous Positive Airway Pressure; [\%] - Oxygen concentration; RE Spontaneous Breathing. Note: One same child may have used all oxygen supply devices, this way the number does not match the total of PTNB. 
Most children in the sample used oxygen ( $n=148 ; 81.77 \%)$ predominantly through the mask ( $n=141 ; 77.90 \%)$ and tracheal tube $(n=100$; $55.25 \%$ ) devices The device used for longer was the tracheal tube, with an average of 15.14 days of use, followed by the mask, with 9.10 days of use. As for the oxygen concentration offered, it remained around $40 \%$ when observing the data from all devices. However, the case that demanded a higher average concentration was the halo with $45.33 \%$, followed by the tracheal tube with $39.34 \%$ of oxygen concentration.

Table 2 shows the association between the use of oxygen and the development of ROP, with data from the two evaluations written in the NICU's medical chart and in the ophthalmologic outpatient follow-up chart.

Table 2 - Relation between the use of oxygen and the development of ROP in the evaluations carried out by the NICU and follow-up institution ( $n=181$ ). Cascavel, Paraná, Brazil, 2017.

\begin{tabular}{|c|c|c|c|c|c|c|c|c|c|c|c|c|}
\hline \multirow{3}{*}{$\mathrm{O}_{2} / \mathrm{ROP}$ ratio } & \multicolumn{6}{|c|}{ Neonatal Intensive Care Unit } & \multicolumn{6}{|c|}{ Follow-up service } \\
\hline & \multicolumn{2}{|c|}{ Without ROP } & \multicolumn{2}{|c|}{ With ROP } & \multirow{2}{*}{$\mathbf{p}-\mathbf{v}$} & \multirow{2}{*}{ OR } & \multicolumn{2}{|c|}{ Without ROP } & \multicolumn{2}{|c|}{ With ROP } & \multirow{2}{*}{$\mathbf{p}-\mathbf{v}$} & \multirow{2}{*}{ OR } \\
\hline & A & SD & A & SD & & & A & SD & A & SD & & \\
\hline Tube Time & $3.93 a$ & 8.45 & $26.43 b$ & 19.47 & \multirow{2}{*}{$<0.001 *$} & \multirow{2}{*}{40.64} & $4.19 \mathrm{a}$ & 8.69 & $19.63 b$ & 20.20 & \multirow{2}{*}{$<0.001^{*}$} & \multirow{2}{*}{7.27} \\
\hline [\%] Tube & $16.62 a$ & 19.48 & $41.96 \mathrm{~b}$ & 9.80 & & & $16.21 a$ & 19.19 & $36.23 b$ & 17.03 & & \\
\hline Time with the mask & $5.34 a$ & 7.12 & $14.40 \mathrm{~b}$ & 9.99 & \multirow{2}{*}{$<0.001^{*}$} & \multirow{2}{*}{5.77} & $5.68 \mathrm{a}$ & 7.93 & $10.98 \mathrm{~b}$ & 8.95 & \multirow{2}{*}{$<0.002^{*}$} & \multirow{2}{*}{5.74} \\
\hline [\%] Mask & $26.14 a$ & 16.16 & $32.98 \mathrm{~b}$ & 9.89 & & & $25.77 a$ & 16.73 & $32.15 a$ & 9.36 & & \\
\hline Catheter Time & $1.30 \mathrm{a}$ & 3.71 & $5.31 \mathrm{~b}$ & 7.42 & \multirow[b]{2}{*}{$<0.001^{*}$} & \multirow[b]{2}{*}{6.00} & $1.31 \mathrm{a}$ & 3.79 & $4.21 \mathrm{~b}$ & 6.73 & \multirow[b]{2}{*}{$<0.001^{*}$} & \multirow[b]{2}{*}{3.27} \\
\hline [\%] Catheter & $9.18 \mathrm{a}$ & 16.71 & $24.82 \mathrm{~b}$ & 19.27 & & & $9.35 \mathrm{a}$ & 16.69 & $20.10 \mathrm{~b}$ & 20.19 & & \\
\hline Halo time & $0.08 a$ & 0.37 & $0.08 a$ & 0.51 & \multirow{2}{*}{0.69} & \multirow[b]{2}{*}{0.45} & $0.09 a$ & 0.39 & $0.06 a$ & 0.43 & \multirow[b]{2}{*}{0.29} & \multirow[b]{2}{*}{0.29} \\
\hline [\%] Halo & $2.60 a$ & 10.38 & $2.09 a$ & 12.39 & & & $2.86 a$ & 10.84 & $1.53 a$ & 10.58 & & \\
\hline Time of SB & $18.69 a$ & 9.68 & $18.46 a$ & 10.32 & & \multirow[b]{2}{*}{--} & $18.35 a$ & 10.01 & $19,48 a$ & 9.14 & \multirow[b]{2}{*}{--} & \multirow[b]{2}{*}{--} \\
\hline [\%] SB & $21.00 \mathrm{a}$ & 0.00 & $21.00 a$ & 0.00 & & & $21.00 \mathrm{a}$ & 0.00 & $21.00 \mathrm{a}$ & 0.00 & & \\
\hline
\end{tabular}

Source: Research database. 2017. Caption: $\mathrm{O}_{2}$ - Oxygen; ROP - Retinopathy of Prematurity; A - Average; SD - Standard Deviation; OR - Odds Ratio; Tube - Tracheal Tube; Catheter - Continuous Positive Airway Pressure; [\%] - Oxygen Concentration; SB - Spontaneous Breathing; different letters (a and b) represent significant difference between the variables obtained by the Kruskal Wallis test with 5\% of significance; * it gives statistic significance. The variables in bold represent the ones that showed significant mean difference for the absence and presence of ROP. We measured the time of oxygen use in days.

Table 3 - Discriminant analysis of variables associated with oxygen use. Cascavel, Paraná, Brazil, 2017

\begin{tabular}{lcc}
\hline $\begin{array}{l}\text { Standardized coefficients of the } \\
\text { discriminant function }\end{array}$ & $\begin{array}{l}\text { Neonatal } \\
\text { intensive } \\
\text { care unit }\end{array}$ & Follow-up \\
\hline Tube Time & -0.886 & -0.821 \\
Oxygen Concentration Tube & -0.188 & -0.333 \\
Time with the mask & -0.213 & 0.249 \\
Oxygen Concentration Mask & 0.154 & 0.012 \\
Catheter Time & -0.288 & -0.374 \\
Concentration Oxygen Catheter & -0.168 & -0.111 \\
Overall accuracy (x100) (a) & 87.85 & 77.90 \\
Proportional Chance Criterion (x100) & 68.80 & 61.03 \\
\% error in the group "without ROP" & 4.97 & 5.52 \\
\% error in the group "with" & 7.18 & 16.58 \\
\hline
\end{tabular}

Source: Research database. Caption: (a): \% of correct classifications; Tube: Tracheal tube; Catheter: continuous positive airway pressure.

The variables that showed statistically significant results when compared to groups without ROP and with ROP were: time of $\mathrm{O}_{2}$ use and $\mathrm{O}_{2}$ concentration in the tracheal tube ( $\mathrm{p}$-value $<0.001$; $\mathrm{OR}-40.64$ ); time of mask use ( $p$-value $<0.001$; $O R-5.77$ ); and time and concentration of $\mathrm{O}_{2}$ of CPAP ( $p$-value $<0.001$; OR -6.00 ). The use of halo ( $p$-value $<0.69$; OR -0.45 ) did not show significant association with the presence or the absence of ROP. All other types of exposure showed association with the presence of ROP. This is also indicated by obtaining an odds ratio higher than one.

We applied a discriminant analysis to classify the premature newborns regarding the presence of ROP, based on the variables of oxygen use, for each of moment (NICU hospitalization and follow-up institution). The results of discriminant analysis are described in Table 3.
This discriminant analysis obtained a percentage of correct classifications higher than 75\%, and also higher than the value of the proportional chance criterion - $\mathrm{Cpro}^{(15)}$. The highest percentage of errors occurred in the group with presence of ROP, this being the largest among the follow-up data.

The standardized coefficients of the function that discriminates the two groups in "without ROP" and "with ROP", whose values range from -1 to 1 , showed that the closer these values are to the coefficients of these variables, the greater the influence of these variables in the discrimination of the two groups. We observed that the variables that mostly influenced the discrimination of both groups were the time of use, tracheal tube and CPAP, because their absolute values were the highest. Considering its values are negative, we can assume that higher values indicate individuals belong to the group with presence of ROP.

Table 4 shows the presence of ROP considering its severity degrees and affected zones by dividing it according to the affected eye at the two evaluation moments and also from children diagnosed with ROP in more advanced degree who needed treatment.

Regarding the presence of ROP in the NICU, 19.34 (35\%) PTBN have been diagnosed with some degree of ROP. In both eyes, the degree one of ROP predominated (RE - 65.11\% and LE -69.39\%). Later, when evaluating medical charts from the follow-up institution, the number of cases of ROP increased to up to $50(27.6 \%)$. The degree one still predominated (RE - 68\% and LE - 56\%) in both eyes. Among these, ten (5.5\%) children had severe ROP, two of them showing degree two and six showing degree three. However, one of them, despite presenting degree one associated with neovascularization, needed treatment. Among the ten babies who developed ROP 3, one had the RE affected and six of them developed ROP 3 in both eyes. 
Table 4 - Classification of ROP according to its presence and degree in both eyes. Cascavel, Paraná, Brazil, 2017

\begin{tabular}{|c|c|c|c|c|c|c|c|c|c|c|c|c|}
\hline \multirow{4}{*}{ Left eye ROP } & \multicolumn{12}{|c|}{ Evaluation of children in Neonatal Intensive Care Unit $(\mathbf{N}=181)$} \\
\hline & \multirow{2}{*}{\multicolumn{2}{|c|}{ Without ROP }} & \multicolumn{4}{|c|}{ Right eye ROP } & \multirow{2}{*}{\multicolumn{2}{|c|}{ G3 }} & \multirow{2}{*}{\multicolumn{2}{|c|}{ G4 }} & \multicolumn{2}{|c|}{ Total } \\
\hline & & & & & & & & & & & & \\
\hline & $\mathbf{N}$ & $\%$ & $\mathbf{N}$ & $\%$ & $\mathbf{N}$ & $\%$ & $\mathbf{N}$ & $\%$ & $\mathbf{N}$ & $\%$ & $\mathbf{N}$ & $\%$ \\
\hline Without ROP & 146 & 80.67 & 1 & 0.55 & 0 & 0.0 & 0 & 0.0 & 0 & 0 & 147 & 81.22 \\
\hline G1 & 0 & 0 & 13 & 7.19 & 2 & 1.1 & 0 & 0 & 0 & 0 & 15 & 8.29 \\
\hline G2 & 0 & 0 & 1 & 0.55 & 7 & 3.87 & 1 & 0.55 & 0 & 0 & 9 & 4.97 \\
\hline G3 & 0 & 0 & 0 & 0 & 2 & 1.1 & 7 & 3.87 & 0 & 0 & 9 & 4.97 \\
\hline G4 & 0 & 0 & 0 & 0 & 0 & 0 & 0 & 0 & 1 & 0.55 & 1 & 0.55 \\
\hline Total & 146 & 80.67 & 15 & 8.29 & 11 & 6.07 & 8 & 4.42 & 1 & 0.55 & 181 & 100 \\
\hline
\end{tabular}

\begin{tabular}{|c|c|c|c|c|c|c|c|c|c|c|}
\hline \multirow{3}{*}{ Left eye ROP } & \multicolumn{8}{|c|}{ Right eye ROP } & \multirow{2}{*}{\multicolumn{2}{|c|}{ Total }} \\
\hline & \multicolumn{2}{|c|}{ Without ROP } & \multicolumn{2}{|c|}{ G1 } & \multicolumn{2}{|c|}{ G2 } & \multicolumn{2}{|c|}{ G3 } & & \\
\hline & $\mathbf{N}$ & $\%$ & $\mathbf{N}$ & $\%$ & $\mathbf{N}$ & $\%$ & $\mathbf{N}$ & $\%$ & $\mathbf{N}$ & $\%$ \\
\hline Without ROP & 1 & 2 & 1 & 2 & 0 & 0 & 0 & 0.0 & 2 & 4 \\
\hline G1 & 7 & 14 & 25 & 50 & 1 & 2 & 1 & 2 & 34 & 68 \\
\hline $\mathrm{G} 2$ & 0 & 0 & 4 & 2 & 3 & 6 & 2 & 4 & 9 & 18 \\
\hline G3 & 0 & 0 & 0 & 0 & 0 & 0 & 7 & 14 & 7 & 14 \\
\hline Total & 8 & 16 & 28 & 56 & 4 & 8 & 10 & 20 & 50 & 100 \\
\hline RE Zone & & & 3 & 6 & 16 & 32 & 31 & 62 & 50 & 100 \\
\hline LE Zone & & & 1 & 2 & 15 & 30 & 34 & 68 & 50 & 100 \\
\hline
\end{tabular}

\begin{tabular}{|c|c|c|c|c|c|c|c|c|}
\hline \multirow{3}{*}{ LE/RE } & \multicolumn{8}{|c|}{ Evaluation of severe ROP cases $(\mathrm{N}=10)$} \\
\hline & \multicolumn{2}{|c|}{ G1 } & \multicolumn{2}{|c|}{ G2 } & \multicolumn{2}{|c|}{ G3 } & \multicolumn{2}{|c|}{ Total } \\
\hline & $\mathbf{N}$ & $\%$ & $\mathbf{N}$ & $\%$ & $\mathbf{N}$ & $\%$ & $\mathbf{N}$ & $\%$ \\
\hline G1 & 1 & 10 & 0 & 0 & 1 & 10 & 2 & 20 \\
\hline G2 & 0 & 0 & 2 & 20 & 0 & 0 & 2 & 20 \\
\hline G3 & 0 & 0 & 0 & 0 & 6 & 60 & 6 & 60 \\
\hline Total & 1 & 20 & 2 & 20 & 6 & 70 & 10 & 100 \\
\hline RE Zone & 2 & 20 & 5 & 50 & 3 & 30 & 10 & 100 \\
\hline LE Zone & 1 & 10 & 5 & 50 & 4 & 40 & 10 & 100 \\
\hline
\end{tabular}

Source: Search database, 2017. Caption: ROP - Retinopathy of Prematurity; LE - left eye; RE - Right Eye; D1/D2/D3/D4 - Degree of retinopathy one, two, three and four.

We noted that among the babies who had ROP in both eyes, there was a higher percentage of babies in the zone $1(65.11 \%$ in the right eye and $69.39 \%$ in the left) and in zone 3 (62\% in the right eye and $68 \%$ in the left one).

As for the most affected area, among the ten treated babies, there was a higher percentage of babies in zone 2 in both eyes followed by zone 3 , the most severe one, for the RE, with three cases, and four cases for LE.

Table 5 presents the association between diagnosed cases of ROP with the use of oxygen and receiving blood transfusions, another procedure correlated with the emergence of the ROP.

All PTNB diagnosed with ROP used oxygen. From these, $86 \%$ had ROP in the right eye, $98 \%$ in the left eye, and $84 \%$ in both. As for blood transfusion, from the 50 PTNB diagnosed with ROP, 37 (74\%) have received the treatment.

Among the other ophthalmologic diagnostics as sequels of ROP, we found: leucoma, total retinal detachment, hyperopia, low visual response, astigmatism, fibrosis of the macula, squint, absence of visual fixation, eye atrophy and central visual impairment.
Table 5 - PTNB diagnosed with ROP and its association with use of oxygen and blood transfusion ( $n=50)$. Cascavel, Paraná, Brazil, 2017

\begin{tabular}{lcccc}
\hline \multirow{2}{*}{ Characteristics } & \multicolumn{2}{c}{ NO } & \multicolumn{2}{c}{ YES } \\
& N & \% & N & $\%$ \\
\hline Blood transfusion & 13 & 260 & 37 & 74 \\
Use of oxygen & 0 & 0 & 50 & 100 \\
ROP only in the right eye & 7 & 14 & 43 & 86 \\
ROP only in the left eye & 1 & 2 & 49 & 98 \\
ROP in both eyes & 8 & 16 & 42 & 84
\end{tabular}

Source: Research database. 2017.

\section{DISCUSSION}

Regarding the oxygen therapy, this study demonstrated that most PTNB used oxygen, predominantly through a mask and tracheal tube. In another research ${ }^{(9)}$, the authors also found statistical significance in the association between these factors, in which the use of oxygen prevailed in $41.3(6 \%)$ in cases that developed ROP. 
With the increased survival rate of PTNB, there was proportion increase in the prevalence and severity of ROP, one of the major causes of preventable childhood blindness ${ }^{(16)}$. In the mentioned study, $16.6 \%$ of PTNB showed that this morbidity. Researchers came to this diagnosis by fundus autofluorescence evaluation, which is associated with the prolonged use of oxygen therapy.

Oxygen is first mostly used treatment for patients with ROP (71.4\%). The longer the exposure to oxygen, the greater the risk of developing the disease ${ }^{(17)}$. However, in another study on the use of oxygen therapy, researchers found that none of the forms of oxygen administration (mechanical ventilation, CPAP) showed statistical association with $\mathrm{ROP}^{(10)}$.

A study ${ }^{(18)}$ concluded that the progression from stage 2 to 3 of ROP in premature newborns significantly dropped after implementing the oxygen therapy protocol, without necessarily contributing to pulmonary morbidity. The authors also suggest that the appropriate oxygen therapy may prevent the progression of ROP of stage 2, potentially decreasing the risk of vision impairment throughout life in this vulnerable population.

In premature birth, oxygen supply to PTNB causes hyperoxia, which triggers vasoconstriction, vascular obliteration, peripheral ischemia and the permanent interruption of retinal vascular formation and may cause the overproduction of Vascular Endothelial Growth Factor (VEGF) and contribute to unwanted retinal neovascularization and the emergence of other ROP complications ${ }^{(6)}$, which justifies the predominance of ROP in PTNB for prolonged periods and with higher concentrations of oxygen.

Therefore, even considering the follow-up procedures and the guidelines to minimize its risk, there was development of ROP. ROP 3 , which was the most serious ROP stage found in PTBN of our study corroborates with the findings of another study that also could not find patients with stages 4 and 5, showing higher incidence of ROP of the remaining stages in one or both eyes in PTBN with shorter gestational age and lower weight. Data on which eye presented ROP was not relevant for this study.

In this study, despite presenting the most severe cases, whose the most affected zone was the 3, requiring laser treatment, we observed a predominance of ROP in zone 2 , which corroborates with study ${ }^{(20)}$, showing that the mostly affected zone was considered of stage 3 .

Another study conducted in 2015 on the incidence and severity of ROP in Turkey ${ }^{(21)}$ comprised a sample of 15,745 PTNB and found out that $30 \%$ of patients presented some degree of ROP and $5 \%$ showed severe ROP, corroborating with our findings. Around $8.2 \%$ of babies showed severe ROP, weighing $1,500 \mathrm{~g}$ and $\leq 0.6 \%$ of babies weighing $>1,500 \mathrm{~g}$. From all children diagnosed with ROP, $16.5 \%$ required photocoagulation with laser and 20 patients born with $>32$ weeks of gestational age also needed to this treatment. A total of 28 PTNB with severe ROP underwent vitreous surgery. A total of 23 patients with gestational age $\leq 28$ weeks, and 5 with gestational age from 29 to 32 weeks, implying that our findings suggest that more premature babies are more at risk of severe ROP that requires treatment.

In Costa Rica, a study developed with a sample of 3,018 PTBN found ROP in 585 patients (19.4\%). From these, 15.4\% (90 patients) required laser treatment, and $53 \%$ of those who needed treatment weighted $<1.000 \mathrm{~g}$. Five babies who needed treatment had $\geq 32$ weeks of gestational age, but weighted $\leq 1,750 \mathrm{~g}$. This study has diagnosed rush disease disease in nine patients, and two infants of selected individuals (0.07\%) suffered severe visual impairment during the study period of five years ${ }^{(22)}$.

From the 50 PTNB who developed ROP in this study, we noted the disease was more prevalent in those who also needed to perform blood transfusion (74\%), in addition to oxygen therapy. In a similar study ${ }^{(9)}$, we observed the statistical significance in this association, which showed that blood transfusion prevailed in $86.6 \%$ of cases that developed ROP.

The study ${ }^{(23)}$ that evaluated blood transfusions performed in NICU for ROP found that nine our of nine PTNB with ROP belonged to the group that had performed blood transfusions. They also found that the highest number of blood transfusions was statistically associated with a higher incidence of ROP. However, the relation between ROP and blood transfusion has not been completely clarified.

Another research ${ }^{(10)}$ on blood transfusions as risk factors correlated with the development of ROP has shown that the use of blood transfusions significantly contributed to the disease, which resembles with the findings of this study.

Still concerning the important risk factors associated with ROP, authors ${ }^{(16)}$ mention oxygen therapy and the number of blood transfusions among other findings, corroborating with our results as they show to be significant for the presence of ROP.

\section{Study limitations}

Despite being small, the number of evaluated patient charts has shown the associations that corroborate with the findings of other studies. Further studies on this matter are important, especially to evaluate the existing ROP screening protocols and the role of nursing in the prevention of ROP developed during hospitalizations in NICU.

A still recurrent problem in retrospective cohort studies of observation is to separate the effects of main exhibition of those produced by other factors or extrinsic variables. Thus, extrinsic and confounding variable can mask a possible association between exposure and disease factor, influencing the results.

\section{Contributions to the field of nursing, health or public policy}

Our findings allow us to reflect on the role of nursing in prevention, diagnosis, monitoring and the follow-up treatment of PTNB with predisposition to ROP in intensive care environments. By basing on the found diagnostic data, it was possible to consider strategies like the establishment of protocols of care both for oxygen therapy and blood transfusions, implying the training of the whole nursing team, due to its correlation with ROP. The nursing team, under the supervision of the main nurse, is responsible for implementing and conducting the follow up of such practices, their role being essential to minimize the problem.

\section{CONCLUSION}

This study showed the association between oxygen therapy and the emergence of ROP in PTNB, reinforcing the need to adopt well-established protocols for the strict control of the time and form of administration of oxygen. It is of vital importance for the NICU, as well as for procedures such as blood transfusions, which showed association with the development of ROP. 


\section{REFERENCES}

1. Ambrósio CR, Silva CHM, Melo EGA. Aspectos éticos do nascimento no limite de viabilidade. Rev Med Minas Gerais [Internet]. 2015 [cited 2018 Jan 20];25(4):511-516. Available from: http://rmmg.org/artigo/detalhes/1864

2. World Health Organization (WHO). Born too soon: the global action report on preterm birth. Geneva: WHO; 2012 [cited 2016 June 5]. Available from: http://www.who.int/mediacentre/factsheets/fs363/en

3. Balbi B, Carvalhaes MABL, Parada CMGL. Temporal trends of preterm birth and its determinants over a decade. Ciênc Saúde Colet [Internet]. 2016 [cited 2019 Jan 10];21(1):233-241. Available from: http://www.scielo.br/pdf/csc/v21n1/1413-8123-csc-21-01-0233.pdf

4. Damian A, Waterkemper R, Paludo CA. [Profile of neonates hospitalized at a neonatal intensive care unit: a cross-sectional study]. Arq Ciênc Saúde. 2016;23(2):100-5. Portuguese.

5. Cavagnoli A, Taglietti M. Monitoramento da oxigenioterapia em recém-nascidos hospitalizados na unidade de terapia intensiva neonatal. FIEP Bulletin [Internet]. 2014 [cited 2018 Jan 22];84(II). Available from: http://www.fiepbulletin.net/index.php/fiepbulletin/article/view/4572

6. Tartarella MB, Fortes Filho JB. Retinopathy of prematurity. Rev Dig Oftalmo [Internet]. 2016 [cited 2018 Jan 16];2(4):1-16. Available from: https://e-Oftalmo.emnuvens.com.br/cbo/article/view/74/74_Atualiza\%C3\%A7\%C3\%A3o_pt

7. Moinho R, Morais S, Monteiro M, Mimoso G. Retinopathy of prematurity in a neonatal intensive care unit: experience of eight years. Acta Pediatr Port. 2015 [cited 2018 Feb 5];46:198-204. Available from: http://actapediatrica.spp.pt/article/view/5945/5235

8. Silva FC, Falco HCBB, Silva FG, Carvalho PK. Retinopathy of prematurity: perinatal risk factors. Semina cienc biol saude [Internet]. 2016 [cited 2019 Jan 10];37(1):3-14. Available from: http://www.uel.br/revistas/uel/index.php/seminabio/article/view/22338/19202

9. Theiss MB, Grumann Jr A, Rodrigues MRW. Epidemiologic profile of preterm infants with retinopathy of prematurity in the Dr. Homero de Miranda Gomes Regional Hospital in São José. Rev Bras Oftalmol [Internet]. 2016 [cited 2017 Dec 6];75(2):109-14. Available from: http:// www.scielo.br/pdf/rbof/v75n2/0034-7280-rbof-75-02-0109.pdf

10. Gonçalves E, Násser LS, Martelli DR, Alkmim IR, Mourão TV, Caldeira AP et al. Incidence and risk factors for retinopathy of prematurity in a Brazilian reference service. São Paulo Med J. 2014 [cited 2019 Jan 10];132(2):85-91. Available from: http://www.scielo.br/pdf/spmj/ v132n2/1516-3180-spmj-132-02-00085.pdf

11. Azami M, Jaafari Z, Rahmati S, Farahani AD, Badfar G. Prevalence and risk factors of retinopathy of prematurity in Iran: a systematic review and meta-analysis. BMC ophthalmol [Internet]. 2018 [cited 2019 Jan 10];18(83):1-14. Available from: https://www.ncbi.nlm.nih.gov/pmc/ articles/PMC5879798/

12. Ludwig CA, Chen TA, Hernandez-Boussard T, Moshfeghi AA, Moshfeghi DM. The epidemiology of retinopathy of prematurity in the United States. Ophthalmic Surg Lasers Imaging Retina. [Internet]. 2017 [cited 2019 Jan 10];48(7):553-562. Available from: https://www.ncbi.nlm.nih. gov/pubmed/28728176

13. Agência Nacional de Saúde Suplementar (ANS). Relatório da revisão do rol de procedimentos e eventos em saúde - 2018 para submissão à consulta pública. Rio de Janeiro: ANS; 2017 [cited 2018 Jan 22]. Available from: http://www.ans.gov.br/images/Relatorio_CP_ final_26.06.2017.pdf

14. Bassab WO, Miazaki ES, Andrade DF. Introdução à análise de agrupamento. São Paulo: Associação Brasileira de Estatística; 1990.

15. Hair JF, Anderson RE, Tatham R, Black WC. Análise multivariada de dados. 5. ed. Porto Alegre: Bookmann; 2007.

16. Sousa DS, Sousa Jr AS, Santos ADR, Melo EV, Lima SO, Santos MA et al. Morbidity in extreme low birth weight newborns hospitalized in a high risk public maternity. Rev Bras Saúde Matern Infant [Internet]. 2017 [cited 2018 Jan 21];17(1):149-157. Available from: http://www. scielo.br/pdf/rbsmi/v17n1/pt_1519-3829-rbsmi-17-01-0139.pdf

17. Carmona OLB, Gonzalez YT, Garcia MS, Armas MM, Martinez RR, Polanco SL, et al. Comportamento de retinopatia de prematuridade na província de Havana. Cuban J Ophthalmol [Internet]. 2013 [cited 2017 Nov 30];26(2):1-8. Available from: http//scielo.sld.cu/scielo.php? script=sci-arttext\&pid=S0864-21762013000200012

18. Colaizy TT, Longmuir S, Gertsch K, Abràmoff MD, Klein JM. Use of a supplemental oxygen protocol to suppress progression of retinopathy of prematurity. Invest Ophthalmol Vis Sci [Internet]. 2017 [cited 2018 Jan 28];58(2):887-91. Available from:

19. Reyes ZS, Al-Mulaabed SW, Bataclan F, Montemayor C, Ganesh A, Al-Zuhaibi S et al. Retinopathy of prematurity: revisiting incidence and risk factors from Oman compared to other countries. Oman J Ophthalmol [Internet]. 2017 [cited 2018 Jan 5];10(1):26-32. Available from: https:// www.ncbi.nlm.nih.gov/pmc/articles/PMC5338048/?report=printable

20. Kara C, Petriçli IS, Hekmoglu E, Akil H, Beyazyldiz O. Treatment success of laser therapy for retinopathy of prematurity in referred and non-referred patients. Arq. Bras Oftalmol [Internet]. 2016 [cited 2018 Jan 29];79(2):96-9. Available from: http://www.scielo.br/pdf/abo/ v79n2/0004-2749-abo-79-02-0096.pdf

21. Jefferies AL. Retinopathy of prematurity: an update on screening and management. Paediatr Child Health. 2016 [cited 2018 Jan 30];21(2):101-4. Available from: https://www.cps.ca/en/documents/position/retinopathy-of-prematurity-screening\#

22. Tabarez-Carvajal AC, Montes-Cantillo M, Unkrich KH, Trivedi RH, Peterseim MMW. Retinopathy of prematurity: screening and treatment in Costa Rica. Br J Ophthalmol [Internet]. 2017 [cited 2018 Jan 31];101(12):1709-13. Available from: http://bjo.bmj.com/content/101/12/1709 
23. Correia CR, Parreira L, Aguiar M, Tuna ML. Red blood cell transfusion in very low birth weight infants and/or infants less than 32 weeks of gestational age - 4 years experience in a neonatal intensive care unit. Nascer crescer. 2016 [cited 2018 Jan 10];25(2):77-82. Available from: http://www.scielo.mec.pt/pdf/nas/v25n2/v25n2a04.pdf 